\title{
SINAIS DE SALVAÇÃO: CATEQUESE E SOTERIOLOGIA DOS ESCRAVOS NA VISÃO DOS JESUÍTAS NAS AMÉRICAS (SÉCULOS XVII E XVIII)
}

Signos de La salvación: Catequesis y soteriología de los esclavos por
los jesuitas en las Américas (Siglos XVII y XVIII)

Carlos Engemann *

\begin{abstract}
RESUMO
Este artigo tem como objetivo analisar os fundamentos da catequese dos africanos e seus descendentes, especialmente os sermóes dos padres da Companhia de Jesus na América Ibérica nos séculos XVI e XVIII. Procuramos descobrir, a partir de debate teológico estabelecido desde o século XVI entre católicos e reformadores, aqui parcialmente reconstruído pelo Concílio de Trento e pela Confissão de Augsburg, quais foram os elementos-chave na pregaçáo dos jesuítas para os seus escravos ou os de seu contato, como no caso de Alonso de Sandoval e Pedro Claver em Cartagena. Objetivou-se, ainda, comparar os escritos de Sandoval com os sermóes de Antônio Vieira, no Brasil, à procura de itens que visam um padrão doutrinário entre eles.
\end{abstract}

Palavras-chave: Igreja Católica, escravidão, Companhia de Jesus.

\footnotetext{
"Mestrado em História - Universidade Salgado de Oliveira (UNIVERSO), Niterói, Brasil. Correo electrónico: carlos. engemann@gmail.com

Artículo recibido el 4 de febrero de 2013. Aceptado el 6 de noviembre de 2013.
} 


\title{
RESUMEN
}

Este artículo tiene como objetivo analizar los aspectos fundamentales de la catequesis de los africanos y sus descendentes, especialmente las predicas de los sacerdotes de la Compañía de Jesús en América ibérica en los siglos XVI al XVIII. Buscamos descubrir, a partir del debate teológico establecido desde el siglo XVI entre católicos y reformistas, aquí parcialmente reconstruido por el Concilio de Trento y por la Confesión de Augsburgo, cuáles fueron los elementos clave en la predicación de los jesuitas a sus esclavos o los de su contacto, como en el caso de Alonso de Sandoval y Pedro Claver, en Cartagena. Hemos tratado aún, de comparar los escritos de Sandoval con los sermones de Antonio Vieira en Brasil, buscando elementos que apunten un padrón doctrinario entre ellos.

Palabras claves: Iglesia Católica, Esclavitud, Compañía de Jesús.

\begin{abstract}
This article aims to analyze the fundamentals of African's catechesis and their descendants; particularly the sermons of the priests of Society of Jesus in Iberian America between sixteenth and eighteenth centuries. We intent to know the keyelements in Jesuits' preaching to their slaves or slaves of their contact, as Alonso de Sandoval and Pedro Claver in Cartagena. We start from theological debate established since the sixteenth century between Catholics and reformers, partially reconstructed by the Council of Trent and the Augsburg Confession. The goal of this work was also to compare the writings of Sandoval with the Antonio Vieira's sermons from Brazil, looking for elements that show a doctrinal standard between them.
\end{abstract}

Keywords: Catholic Church, Slavery, Society of Jesus.

\section{CATEQUESE E ALTERIDADE}

Mesmo antes de chegar à América, os jesuítas já conheciam, e entendiam como parte de sua missão, os esforços de evangelização de africanos. Tanto para os que ingressaram na Companhia de Jesus em Portugal quanto para os que o fizeram na Espanha, os esforços para a conversão de populaçóes africanas já eram consideravelmente familiares. Aos jovens postulantes a jesuíta portugueses seriam estimulantes as narrativas de reis e súditos africanos batizados em suas terras ou mesmo em Lisboa (Souza, 2006: 281). Escritos de outros sacerdotes, que acompanharam viagens de exploração ou mercantis, facilmente concorreriam para 
talhar nos sonhos missionários de jovens inacianos o quão virtuoso seria colaborar para salvação de tão numerosas almas, que jaziam nas trevas do paganismo ou da infidelidade maometana.

Os espanhóis, por seu turno, também conheciam de longa data os esforços empreendidos pelo clero para converter escravos infiéis remanescentes na Península, assim como os capturados entre habitantes das Canárias e os adquiridos por meio de comércio com africanos ou portugueses. Com o incremento da compra de escravos oriundos de regióes cada vez mais ao sul, continente africano adentro, o intento de catequizar e converter os negros, que chegavam às cidades de Maiorca e da Catalunha, passou a estar cada vez mais no horizonte religioso do clero inaciano espanhol. Esses negros escravizados alcançavam a Península pelas mãos de traficantes de escravos, que distribuíam o resultado de seu trato com comerciantes do norte da África, para o restante da Espanha (Azopardo, 2012). Além disso, os escravos vindos da Guiné, que eram introduzidos na Península pelos portugueses pelo porto de Lisboa, também chegavam a Sevilla, de onde poderiam ser mandados para outras cidades. Em resumo, o projeto de evangelização de negros escravizados vindos da África não é uma invenção do clero americano, seja da América portuguesa seja da espanhola. Já o havia na Europa ibérica bem antes dos africanos chegarem à América.

As origens mais remotas deste movimento, que busca a transformação do outro em parte de si, podem ser encontradas numa série de açóes empreendidas por elementos do catolicismo, paralelamente à organização das Cruzadas. Exemplos destas iniciativas são ações como: o esforço de Pedro, o venerável, que pagou por uma tradução do Alcoráo para poder refutar o que considerava serem os seus erros e a redação da Suma contra os gentios por Tomás de Aquino. O que a princípio seria um projeto de conversão dos infiéis e pagáos em geral, pouco a pouco foi se convertendo num projeto de evangelização voltado para os negros escravizados.

As bases desse projeto catequético são mais bem conhecidas para a Espanha que para Portugal. Talvez isso se deva ao fato de que sínodos e concílios locais espanhóis mencionarem a obrigação e a necessidade dos padres pregarem e instruírem os pagãos e mesmo os cristãos, imersos em (quase) total ignorância a respeito da doutrina católica, fruto, possivelmente, dos muitos anos de domínio islâmico. Assim, arcebispos de várias cidades -como Toledo, Sevilha e Granada - estabeleceram regras ou diretrizes para a evangelização em seus arcebispados 
(García Villoslada y Llorca, 1960: 597-612). Essas diretrizes foram ratificadas pelos sínodos e concílios celebrados em Aranda, Sevilha e Salamanca.

A catequese de escravos africanos -assim como a dos índios- seguiu mais ou menos o mesmo modelo, ditado pelo Concílio de Trento. O momento de que se trata aqui, não custa ressaltar, é profundamente marcado por debates e açôes motivados pelos questionamentos e refutaçóes lançados pelos reformadores contra a doutrina católica. Nesse sentido, pontos fundamentais nos alicerces do edifício teológico católico estavam sendo desacreditados pelos pregadores reformados. Para a Igreja urgia que se ensinasse a versão católica da doutrina e se aclarasse os pontos dogmáticos e litúrgicos onde o questionamento havia lançado sombras.

No Novo Mundo, a necessidade era de que se criasse, nos domínios dos Reis Católicos, uma barreira às chamadas "doutrinas estranhas". O cooptação de populaçóes se fazia preferencialmente pelo batismo, sacramento que receberá especial atenção neste trabalho pelo seu amplo significado para a doutrina católica, em especial no contexto do qual aqui se trata. Tomaremos como base, o Concílio de Trento e as suas adaptaçóes para as Américas, feita por meio de Sínodos locais junto com pregaçóes e textos de padres da Companhia de Jesus sobre o batismo ou sobre a pregação para os negros escravizados antes e depois do sacramento, entre os séculos XVI e XVIII.

\section{TRENTO, REFORMA E O VALOR DA CATEQUESE}

Em função do confronto com os reformadores, a questão da Justificação do Homem torna-se de central importância para os conciliares reunidos "em tempos tão revoltos", nas palavras do papa Paulo III, na cidade de Trento. Alguns anos antes da convocação do Concílio, e certamente um de seus provocadores, o luteranismo havia publicado um documento trazendo a lume sua doutrina. Trata-se do texto conhecido como Confissão de Augsburgo, preparado por Felipe Melanchthon, com base em outros textos que foram produzidos para a Dieta de Augsburgo, convocada por Carlos V. Resultando em um documento muito mais preciso e conciso do que o que se gerou em Trento, a Confissão de Augsburgo também representa uma exposição mais madura e detalhada da fé reformada pelo luteranismo, se comparado com as famosas noventa e cinco teses publicadas na porta da catedral de Wittenberg. 
Não obstante tenham concordado no que diz respeito ao pecado original e aos efeitos deste na alma e na economia da salvação, o Concílio e a Confissão divergem consideravelmente sobre o que tornaria o homem justo. Na Confissão:

"Ensina-se também que não podemos alcançar a remissão do pecado e justiça diante de Deus por mérito, obra e satisfação nosso, porém que recebemos remissáo do pecado e nos tornamos justos diante de Deus pela graça, por causa de Jesus Cristo, mediante a fé, quando cremos que Cristo padeceu por nós e que por sua causa os pecados nos são perdoados e nos são dadas justiça e vida eterna" (García Villoslada y Llorca, 1960: 597 612).

Com isso, a ênfase dos reformados foi assentada na crença como fator determinante para a justificação. Resumindo: o remédio para o mal introduzido por Adão na humanidade, que a fez perder seu estado de justiça natural, seria o binômio batismo, para o perdão dos pecados (o original inclusive) e a Fé na função salvífica da morte de Cristo.

O catolicismo vê a questão de uma forma ligeiramente diferente. Reafirmando a sua crença antiga:

“[...] indica a descrição da justificação do pecador, de modo que o trânsito é do estado em que o homem é filho nascido do primeiro Adão, ao estado de graça e de adoçáo dos filhos de Deus através do segundo Adão, Cristo Jesus, nosso Salvador. Esta passagem, ou trânsito, não pode ser alcançada após a pregaçáo do Evangelho, sem o batismo, ou sem o desejo por ele, como está escrito: Só pode entrar no reino dos céus aquele que renasceu da água e do Espírito Santo" (Concílio de Trento, p. 23).

Desse modo, o catolicismo estabelece outro binômio para a justificação: instrução e batismo. Outra diferença marcante é que para os católicos a fé chega pelo ouvido e não apenas pela leitura das letras das Sagradas Escrituras, mas de uma ampla série dos chamados Mistérios da fé, que implicam um profundo envolvimento do fiel com a doutrina específica do catolicismo -e toda a mediação que ela pressupóe para a justificação/salvação da alma. Acresce-se aos mistérios a necessidade das obras, que envolvem o fiel numa série de compromissos de cunho prático, determinando uma jurisdição de controle institucional sobre procedimentos cotidianos.

\section{OS JESUÍTAS E OS DISCURSOS SOBRE OS ESCRAVOS}

Em meio a esse acalorado debate teológico, emerge a ação da Cia de Jesus na América. Muito estudada por sua ação missionária junto aos índios e, até certo 
ponto, pouco estudada por sua posse de escravos, os filhos de Santo Inácio quase nunca foram estudados por sua ação catequética junto aos escravos africanos e afrodescendentes. Salvo duas exceçóes: Alonso de Sandoval e Pedro Claver, pouco se tem pensado numa prática sacramental dos jesuítas para com os cativos trazidos da África ${ }^{1}$.

De um modo geral, os estudos sobre os jesuítas e a escravidão sofreram uma mudança considerável nos últimos anos, os trabalhos publicados até os anos de 1980 costumam ver nos padres da Companhia defensores, ou ao menos validadores da escravidão, ao passo que os estudos mais recentes têm buscado compreender de que forma os inacianos viam os africanos e seus descendentes e como os inseriam estes no seu labor missionário. Gostaríamos de apresentar alguns aspectos da catequese e ação sacramental jesuítica para com seus próprios escravos ou os de seu contato, como no caso de Sandoval e Claver, a partir de outro ângulo. De fato, buscaremos nos distanciar daquilo que singulariza estes personagens e buscar o que os aproxima com a prática missionária da companhia, já bastante considerada para os nativos americanos, mas pensada por poucos autores para os africanos e seus descendentes. Neste sentido nos aproximaremos da análise feita por Juliana Beatriz Almeida de Souza, quando compara Sandoval com Las Casas. Em seu artigo (2006: 38 e 39). Juliana analisa o texto de Sandoval e procura associá-lo, ademais da justificativa da existência da escravidão, ao seu labor missionário entre os etiopes.

Em primeiro lugar, havia o paradoxo de uma ordem missionária possuir como escravos seus potenciais conversos, já que os negros escravizados eram, simultaneamente, força de trabalho e rebanho para os padres da Societas Iesu. Desse modo, é possível considerar que para os jesuítas a escravidão dos gentios da Guiné era uma forma de remediar as carências do trabalho religioso com os cristãos e com os gentios da terra, mas para além disso, certamente também era a gestação de um conjunto de relaçóes a serem conformadas em seus quadros mentais.

\footnotetext{
${ }^{1}$ Para estudos mais recentes sobre estes dois padres de Cartagena ver: para Sandoval: Restrepo, Luz Adriana Maya. Brujería y reconstrucción de identidades entre los africanos y sus descendientes en la Nueva Granada. Bogotá: Ministerio de Cultura, 2005; Restrepo, Eduardo. “DE INSTAURANDA ÆTHIOPUM SALUTE: Sobre las ediciones y características de la obra de Alonso de Sandoval”. Tabula Rasa. Bogotá - Colombia, 3, enero-diciembre de (2005): 13-26 e Souza, Juliana Beatriz Almeida de. "Las Casas, Alonso de Sandoval e a defesa da escravidáo negra". Topoi, 7/12, jan.-jun. (2006): 25-59. Sobre Pedro Claver ver: Arana, Paola Vargas. Pedro Claver y la Labor de Evangelización en Cartagena de Indias (siglo XVII) Fuentes claves para analizar a los africanos en el Nuevo Mundo, Revista de História 155 /2 (2006): 43-79; Splendiani, Ana Maria e Aristizabal, Túlio. Processo de beatificación y canonización de san Pedro Claver. Bogotá: CEJA, 2002, e Valtierra, Ángel. San Pedro Claver: el santo que libertó una raza. Cartagena, Departamento de Publicaciones - Santuario de San Pedro Claver, 1964. Este último texto é representante de uma terceira possibilidade de descrição da relaçấo entre os jesuítas e a escravidão, de caráter mais laudatório que os demais. Nesta mesma tradição, poderíamos citar os textos do jesuíta Serafim Leite, para o Brasil. É preciso que se diga que os trabalhos sobre Claver săo mais escassos dada a raridade de textos próprios do "escravo dos escravos".
} 
$\mathrm{O}$ esforço empreendido pelos sacerdotes que se dedicaram a pensar e, em certo sentido, normatizar as relaçóes escravistas acabaram por estabelecer parâmetros dentro dos quais a posse de escravos por parte da ordem teria que se circunscrever. Em função desses parâmetros, caudatários da crença sobrenatural que sujeitava as relaçóes de poder entre inacianos e seus cativos, a administração da mão de obra escrava nesta ordem possuía características fundamentais específicas.

A primeira delas é oriunda de um traço comum ao clero regular: o apresso pela obediência e o cultivo de uma hierarquia estrita em suas comunidades. Assim, o conflito entre cultivar a humilde obediência aos superiores e o hábito do senhorio privado pareceram incompatíveis aos religiosos. Ao mesmo tempo, acreditavam ser impossível sustentar as casas, colégios e outras dependências sem o uso do braço escravo. ${ }^{2}$ A soluçáo foi a propriedade coletiva sobre os cativos, proibindo-se que qualquer um dos padres da Companhia os possuísse de modo privado. Embora houvesse algumas vozes a exigir que nem mesmo coletivamente se os possuíssem, estas foram, de uma maneira ou de outra, silenciadas ou ignoradas ${ }^{3}$.

A propriedade coletiva cumpria ainda outro papel. Se nenhum jesuíta possuía escravos, então o dilema moral da escravidão estava, ao menos em parte, resolvido. Nenhum cristão -ou possível cristão- era propriedade de nenhum inaciano, eram todos "escravos da religião". Os escravos, que eram alvo de catequese -justificativa maior da própria escravidão -e passíveis de salvação não seriam propriedade privada, mas sim coletiva, eliminando um possível conflito de funçôes. Embora, tal perspectiva não chegue a subverter a ordem da sociedade escravista, ao menos encurtava a distância entre a realidade e o preceito, por si só já bastante considerável.

Nos textos dos jesuítas mais proeminentes que escreveram sobre a escravidão, alguns eixos temáticos são explorados com maior vigor. Se tomarmos como base os escritos de Alonso de Sandoval (Sandoval, 1987: 69) e de Antônio Vieira (Bosi, 2011: 183), ${ }^{4}$ ambos jesuítas com a sua ação concentrada no século XVII, sendo o primeiro na América espanhola e o segundo na América portuguesa, será possível destacar temas comuns. O primeiro é o da explicação da escravidão dos negros por meio do mito de Can. Mas Alonso de Sandoval vai mais longe,

\footnotetext{
${ }^{2}$ Cf. Benci, Jorge. Economia cristã dos senhores no governo dos escravos. São Paulo: Grijalbo, 1977; e Antonil, André João. Cultura e opulência do Brasil por suas Drogas e Minas. Introdução e notas por André Dinis Silva. São Paulo: Editora Universidade de São Paulo, 2007.

${ }^{3}$ Sobre essa discussão ver Alencastro, Luiz Felipe. O Trato dos Viventes: formação do Brasil no Atlântico sul. São Paulo: Cia das Letras, 2000: 164ss.

${ }^{4}$ Para um estudo mais apurado sobre os sermóes de Vieira para os escravos ver: o capítulo intitulado "Vieira ou a cruz da desigualdade” em Bosi, Alfredo. Dialética da colonização. São Paulo: Companhia das Letras, 1992.
} 
se preocupa em resolver o paradoxo de um ancestral judeu para um povo negro. Sendo a referência de judeu dos cristáos o próprio Cristo, pensar que um homem necessariamente branco daria origem ao povo negro cativado nas terras do outro lado do Atlântico, se transformou num problema, que Sandoval soluciona com um recurso a Aristóteles. Segundo o jesuíta, quando perguntaram ao filósofo porque os animais, tanto irracionais como racionais, algumas vezes herdavam características dos pais e outras vezes não, teria respondido que a causa das discrepâncias é a imaginação. Por isso, o que os pais imaginam, pensam e veem interfere na forma dos filhos, por isso de pais belos nascem filhos feios e de pais brancos poderiam nascer filhos negros. Como prova, Sandoval narra ter visto o processo oposto, uma menina branca nascida de pais negros, que certamente tratava-se de um caso de albinismo. Porém para o jesuíta, o motivo da discrepância era a presença de uma cadela branca com manchas que acompanhou a mãe por toda a gestação.

De todo modo, a maldição de Can como mito de origem para a escravidão africana aparece nos discursos dos jesuítas para circunscrever o alvo da escravidáo e para justificar lhe a existência como castigo pelo pecado ancestral. Esta perspectiva de escravidáo como fruto de um castigo permitiu a Antônio Vieira deslocar o sentido do Salmo 87 (Vainfas, 1986: 96) até transformá -lo em expressão da escravidãoredenção. Se a escravidão era produto do pecado, seus padeceres poderiam se converter em fonte de redençáo para os cativos que náo apenas deveriam aceitar o jugo, mas ser gratos por ele. Neste jugo os etíopes se assemelhariam a Cristo nos seus sofrimentos e, assim, poderiam ser recebidos na Cidade Celestial. Aqui se apresenta um escravo humano passível da perversa herança espiritual recebida de Can, mas igualmente passível da Redenção Eterna na sua imitação a Cristo em suas dores. $\mathrm{O}$ cativo poderia nutrir-se de uma esperança excelsa, na certeza de que sua docilidade conduzir-lhe-ia ao Eterno.

Outro conjunto temático relevante deriva deste primeiro e com ele compóem uma réplica da cosmovisáo católica da trajetória da humanidade da Queda à Salvação. De modo análogo ao que se deu com todo o gênero humano na soteriologia católica, isto é, uma longa trajetória da Queda do pecado original até a Salvação eterna, a ser consumada no Juízo Final, os etíopes tiveram seu pecado original em Can, padeceram no paganismo e na escravidão, até que por fim encontraram o catolicismo pregado pelos jesuítas. $\mathrm{O}$ conceito chave neste segundo bloco discursivo é o de "salvação". Embora não entre em pauta diretamente, o conceito de salvação, naturalizado entre os cristãos, implica no conforto para 
o problema da morte. É a busca de uma certeza em meio ao mistério do pósmorte. Mais que isso, insere-se no que Pedro Claver falava aos seus catecúmenos da existência de "um só Deus que premeia ou castiga segundo os merecimentos de cada um” (Valtierra, 1964: 140-141).

\section{OS JESUÍTAS E OS DISCURSOS PARA OS ESCRAVOS}

Como dito anteriormente, o Concílio expressa que a conversão vem pelo ouvir a doutrina, mas em outro sentido, também é possível pensar que a mesma salvação vem do falar. Dito de outro modo, se aos negros chega a salvação pela conversão derivada da pregação dos padres, aos padres esta mesma salvaçáo chega à medida que pregam para o gentios. Isso torna o processo uma via de mão dupla, fazendo da pregação, em última análise, um interesse do próprio pregador, que por meio dela alcança a salvação para si, garantindo um lugar melhor para passar a Eternidade. Esta reflexáo pode ser acrescida de um terceiro braço: os senhores. Os proprietários dos escravos estão sujeitos, de igual modo, a salvação ou a condenaçáo eterna de acordo com o seu comportamento para com os seus escravos. As crueldades são apresentadas, tanto por Sandoval quanto por Vieira, como características de muitos senhores, que espancam e supliciam seus cativos por motivos banais. E mais, se negam a catequizá-los ou permitir que alguém o faça. Daí deriva o caminho para o inferno dos senhores, do abuso de sua autoridade e de negar o páo espiritual aos seus escravos. A crueldade da violência atentava contra os preceitos fundamentais da fraternidade cristã que não significava, nem de longe, igualdade. Porém, negar a instrução religiosa e os sacramentos era algo impensável para os padres da Companhia.

Assim, a fala aos escravos constituía-se parte fundamental em torno da qual girava a soteriologia jesuítica da escravidão. A finalidade deste aparato discursivo é clara: transformar o outro em algo distinto do que ele é. Dito de outro modo, converter o africano escravizado em um cristão com função específica e lugar determinado na sociedade corporativa na qual foi compulsoriamente introduzido. Por isso, Sandoval e Claver, assim como Antônio Vieira e outros depois deles, pregavam aos escravos ter sido uma grande fortuna que tenham sido capturados na África e trazidos às terras onde habitavam cristãos que os instruiriam e batizariam. Afirmavam em seus sermóes aos escravos que o cativeiro terreno era um preço razoável a se pagar, já que não seria comparável ao cativeiro infernal de onde teriam escapado. 
Mais que isso. Empreendiam parte de seu ministério no que acreditavam ser um processo de transformaçáo destes homens e mulheres, chegados com a pecha de gentios, em cristáos católicos e filhos de Deus, capazes, inclusive, de contrair parentesco espiritual e batizar seus filhos por penhor de sua própria fé. Ainda que isso implique em uma integração na sociedade na escala hierárquica mais baixa possível, dotavam-nos de subjetividade sacramental. Ou seja, conferialhes um status suficientemente capaz de serem sujeitos do sacramento, sobre quem repousa todo o peso da eficiência do mesmo ${ }^{5}$.

Segundo o Concílio de Trento, os sacramentos são "por onde começa toda verdadeira santidade, ou começada se aumenta, ou perdida se recobra". A obtenção dos sacramentos são elementos fundamentais na concepção soteriológica católica. O batismo é o primeiro de todos, após o qual vem o crisma e o matrimônio ou a ordem, como sacramentos cujo efeito é uma "marca" indelével no espírito daquele que o recebe e por isso são aplicados uma única vez. A confissão/penitência, a Eucaristia e a unçáo dos enfermos, ou a extrema-unção, podem ser recebidas várias vezes na vida, pois são considerados remédios na manutenção do estado de Graça e sanidade da alma e do corpo.

Vamos nos deter em um sacramento específico, o batismo, para avaliar aspectos da pregação que comportava o discurso dos padres da Societas Iesu para seus cativos, de modo particular os que vinham da África e seus descendentes. ${ }^{6}$ Este sacramento foi escolhido por ser um momento privilegiado para o catecumenato no catolicismo desde os primórdios do cristianismo. Nos primeiros séculos, todo aquele que fosse apresentado por um padrinho, que atestava a sua idoneidade e sinceridade de coraçáo ingressava num período de aprendizagem e preparação (catecumenato). O batismo imediato de conversos só ocorreu na geração apostólica, após esse curto período, os cristãos concluíram que para ingressar na comunidade pela porta das águas batismais havia a necessidade de "[...] uma preparação que consiste numa conversão à fé e numa conversão de vida. Exige uma instrução de ordem moral e de ordem doutrinal. Tudo isso exigia tempo e requeria uma instituição adaptada, a instituição catecumenal.” (Sesboüé et alii, 2005: 60)

Durante a Idade Média o costume de batizar as crianças logo depois de nascer, que se conserva até os dias de hoje, fiando-se na fé de seus pais, eliminou a necessidade de uma pregaçáo que conduzisse à conversão dentro das populaçóes já

\footnotetext{
${ }_{5}^{5}$ Pela teologia sacramental católica, o sacramento tem sua eficácia pelo poder de Cristo que u opera (ex opere operato), mas tem sua eficiência na subjetividade de quem o recebe (ex opere operandi). Cf. Catecismo da Igreja Católica, parágrafo 1128. ${ }^{6}$ Não é de nosso interesse entrar aqui na discussão sobre o estatuto dos indígenas quando trabalhavam para os padres jesuítas.
} 
alcançadas pela fé católica. Chegou-se, pois, ao início da Era dos Descobrimentos, quando novas populaçóes que seriam incorporadas à Cristandade deveriam ser catequizadas, com um sistema catequético mais enxuto que o da Antiguidade, que poderia demandar até três anos de dedicação como ouvinte para que se fosse considerado apto ao batismo.

O Concílio de Trento confere grande importância ao batismo e a catequese pré-batismal, em especial pelos questionamentos dos reformadores. $\mathrm{Na}$ América, tanto o Terceiro Concílio Provincial de Lima quanto o Terceiro Concílio Provincial do México buscam aplicar as fórmulas catequéticas de Trento na América espanhola, o que no caso da América portuguesa só ocorreria muito depois com as Constituiçóes Primeiras do Arcebispado da Bahia. Ou seja, ainda no século XVI, entre os anos de 1582 e 1585, em dois pontos distintos da América espanhola, celebraram-se concílios cujo objetivo era normatizar, segundo as especificaçóes tridentinas, a vida dos católicos nas suas respectivas arquidioceses.

$\mathrm{O}$ ponto de contato, no que toca a esta pesquisa, entre os dois concílios provinciais do século XVI e o seu semelhante do início século XVIII, ocorrido no Brasil, é a existência de cláusulas exigindo que os escravos negros fossem batizados. Além disso, estabeleciam a compreensão da doutrina e o desejo de receber o batismo como condição para o mesmo. Havia também em todos os três documentos a autorização para a simplificação da doutrina em casos específicos: enfermidades graves, muito velhos ou muito rudes. No Concílio Provincial do México fica claro que é proibido levar escravos comprados para as minas ou cárceres sem antes batizá-los, ainda que fossem instruídos de forma precária.

Em suma, os que eram considerados impossibilitados de compreender, ou por uma eventual falta de tempo ou por uma atávica falta de capacidade, poderiam receber uma versão resumida da doutrina católica antes do batismo ${ }^{7}$.

Mas em que consistiria essa catequese dos "muito brutos" ou "rudes"? As Constituiçóes Primeiras mandam que se ensinem:

“[...] e especialmente a seus escravos que são os mais necessitados desta instrução pela sua rudeza, mandando-os à Igreja para que o pároco lhes ensine os Artigos da Fé, para saberem bem crer; o Padre-Nosso, e Ave Maria para saberem bem pedir; os Mandamentos da Lei de Deus, e da Santa Madre Igreja, e os pecados mortais, para saberem bem obrar; as virtudes para que as sigam; e os sete sacramentos para que dignamente os recebam e com eles a Graça que dão, e as mais oraçóes da Doutrina Cristã para que sejam instruídos em tudo, o que importa para a salvação" (Vide, 2007: 2-3).

\footnotetext{
${ }^{7}$ Aos que estavam em perigo de morte poderia se batizar sem doutrinaçấo alguma.
} 
Este esquema sistematiza o conteúdo da doutrina por meio de uma exposiçáo compartimentada dos elementos da fé, que foi usada até bem pouco tempo ${ }^{8}$. O Catecismo Romano, compêndio produzido por determinação do Concílio de Trento, seguiu este modelo, assim como outros antes e depois dele. As partes essenciais eram o sinal da Cruz, as oraçóes (incluindo os chamados atos-como o ato de contrição), o Credo -um dos símbolos com o resumo dos ensinamentos do catolicismo-, os dez mandamentos da Lei de Deus e os mandamentos da Igreja, os sacramentos, os pecados mortais e veniais (interdiçóes), as boas obras (atos que a igreja recomendava $)^{9}$. De posse destes saberes, o fiel poderia ser contado entre os que estavam obrigados a cumprir os preceitos católicos.

A partir destes fundamentos estabelecia-se a obrigatoriedade de casar, frequentar a igreja, jejuar segundo os ditames católicos,... Desse modo, o batismo, como ritual de passagem, introduzia o indivíduo num universo de preceitos e práticas que condicionariam as suas açóes e crenças, ao menos esta era a esperança dos padres que oficiavam tudo.

No entanto, pelos escritos de Alonso de Sandoval, parece-nos que a didática jesuítica era ligeiramente diferente. Tudo começava pela própria cerimônia do batismo, que precisava ser compreendida e desejada, ou ao menos consentida, pelo futuro cristão. Por isso era necessário fazer compreender ao seu interlocutor que sem o batismo ele seria lançado nas chamas eternas, porém uma vez que consentisse passar pelo banho ritual, seu destino seria o paraíso. Uma vez logrado obter pelo medo do inferno o consentimento, cabia mostrar que o ritual de lançar água sobre a cabeça era distinto de uma simples limpeza ou de um banho para aplacar o calor escaldante dos trópicos. Era preciso que os catecúmenos, ainda que "rudes", tomassem a água batismal como uma "agua de Dios".

Antes de passar adiante nos saberes, o jesuíta recomenda que se lhes pergunte tantas vezes quantas sejam necessárias, até que respondam que a água do batismo é a água de Deus, que renunciam aos seus deuses e aceitam o deus dos brancos, que sem ela vão para o inferno, mas com ela vão para o céu,... Para reafirmar o desejo pelo sacramento, recomenda o seguinte:

“También se les dirá luego en este punto que la causa de ser los blancos tan estimados de todos, es, por haber recibido esta agua con que se hicieron cristianos, que si no lo fueran

${ }^{8} \mathrm{O}$ que chamamos de exposiçáo compartimentada consiste em agrupar os saberes em categorias, como artigos da fé (no que se crer), oraçôes (o que pedir), mandamentos (o que fazer e o que não fazer),...

9 Estes elementos foram relacionados baseados no Catecismo Romano e no catecismo intitulado Doutrina Cristä do jesuíta Marcos Jorge, publicada pela primeira vez em 1561. Cf. Martins, Leopoldo Pires, OFM (Ed.), Catecismo Romano. Petrópolis: Ed. Vozes, (1951): 21. 
no hubiera quien hiciera caso de ellos. Que la reciben ellos y serán estimados, como ellos, podrán ir a los templos y casas de Dios, tratar y comer con los demás cristianos y cuando se mueran los enterraran en la Iglesia si son cristianos, o si no en el muladar, donde sean comidos de perros" (Sandoval, 1987: 422).

Alonso de Sandoval aplica de modo bastante pragmático uma pedagogia baseada num deus que premia e castiga, conforme a adesão à pregação. Claver, seu sucessor, legou ao mundo poucos escritos próprios, mas em uma das raras fontes revela um conteúdo possível na catequese dos escravos, baseado no ideário do seu predecessor e mestre. Segundo Pedro Claver, em sua carta de 31 de maio de 1627, após cuidar dos escravos doentes, começavam os preparativos para o batismo.

Depois tratamos de prepará-los para o Batismo. Explicamos lhes os admiráveis efeitos deste sacramento para o corpo e para a alma. E quando, respondendo às nossas perguntas, deram mostras de terem compreendido, passámos a um ensino mais completo sobre um só Deus que premeia ou castiga segundo os merecimentos de cada um, etc. Exortamo-los a fazer o ato de contrição e a manifestar o arrependimento dos pecados que tivessem cometido, etc.

Finalmente, quando já pareciam suficientemente preparados, falamos dos mistérios da Santíssima Trindade, da Encarnação e da Paixão; e, mostrando lhes num quadro a imagem de Cristo crucificado sobre uma pia baptismal, para a qual correm os rios de sangue provenientes das chagas de Cristo, rezámos com eles, na sua língua, o acto de contrição (Valtierra, 1964: 140-141).

Apesar de serem elementos rudimentares da fé católica o escravo dos escravos, como Claver se auto intitulava, apostava na mudança de crença dos escravos recémchegados para o monoteísmo. Além disso, acreditava que os fazia compreender, ainda que superficialmente, o que seriam os efeitos espirituais e materiais do sacramento que estavam prestes a receber. Talvez outros jesuítas não tenham tido a mesma devoção missionária para com os escravos que tiveram Sandoval e Claver em seus anos de trabalho em Cartagena das Índias, mas é possível que houvesse certo padrão de evangelização na Companhia de Jesus, quanto aos saberes rudimentares necessários para ser cristão.

Seguindo o método de Sandoval, (Sandoval, 1987: 421) Claver apresentava um crescente de complexidade no conhecimento transmitido pela catequese. Começando pelo próprio sacramento do batismo, que é explicado afim de que se saiba o que vai acontecer, misticamente falando, na cerimônia - elemento estrutural para a validade do sacramento. Segundo o testemunho de Francisco 
Yolofo, escravo intérprete que trabalhou com Claver, este mandava que lavassem a cabeça todos os escravos que iam ser batizados. A julgar pelo que escreveu Sandoval, este procedimento, aparentemente, tinha a única função de servir de termo de comparação pela negativa (Splendiani e Aristizabal, 2002: 112-118). Por outros meios, Claver fazia com que os negros lavassem a cabeça para lhes mostrar a diferença entre a simples lavagem e o ritual de lavar a alma com as águas do batismo, as águas de Deus. Para que não restassem dúvidas havia, ainda segundo o testemunho de Francisco, um quadro com Cristo crucificado em cujos pés havia uma bacia, para a qual convergiam os fios de sangue que saíam das feridas. Ao lado da bacia, no quadro, se via um padre jesuíta paramentado, diante do qual estava ajoelhado um negro, descrito pelo intérprete como muito bonito, que era batizado com o sangue tirado da bacia com um jarro.

A cerimônia oficiada pelo santo reunia os futuros filhos do deus dos brancos em grupos de dez homens ou dez mulheres, todos receberiam um novo nome. Assim, os dez homens de um mesmo grupo teriam o mesmo nome cristáo, configurando dez juans, ou dez migueis, ou ainda dez pablos; o mesmo se dava com as mulheres. Uma vez batizados os cativos recebiam uma pequena medalha para ser levada pendurada ao pescoço por um fio: de um lado a Virgem e do outro o Cristo. Esta medalha permitia ao jesuíta identificar que já haviam passado pelo rito das águas (Splendiani e Aristizabal, 2002).

Desse modo, o batismo se constituía como uma espécie de rito de passagem. Das múltiplas funçóes do batismo essa nos parece ser a primeira, propor (ou impor, dependendo da situação) um novo processo de ressocialização ao futuro cristáo-católico. Ainda que mais exíguo em seu cabedal de informaçóes, era tão -ou talvez até mais- extenso em termos de implicaçóes comportamentais. Começava, como dito, por conferir um nome cristáo. O novo nome expressava, sem sombra de dúvidas, uma grande esperança dos sacerdotes que pregavam e batizavam as populaçóes não-cristâs de que, como acreditavam que ocorria no plano espiritual, também ocorreria no que tange às heranças e memórias dos seus pretensos discípulos: morreria o homem velho e ressurgiria das águas purificadoras homens e mulheres novos, plenamente cristáos pela posse de algumas informaçóes incutidas com maior ou menor acuidade, dependendo de quem oficiava o processo.

Para Alonso de Sandoval, o primeiro passo no contato com os escravizados deveria ser perguntar-lhes o nome; um nome cristão como resposta era um indicativo de que possivelmente o interlocutor havia sido batizado, ainda que 
restasse aferir a validade. Como visto anteriormente, segundo Trento e os concílios provinciais - incluindo o da Bahia- a validade do sacramento era assentada em dois quesitos fundamentais: a instrução e o consentimento. É possível que muitos padres fizessem o mínimo possível, apenas o suficiente para se desobrigar da tarefa e, caso ainda acreditassem, não serem acusados da danação daquelas almas no Dia do Juízo, mas esse mínimo náo era táo simples quanto possa parecer.

Para a Igreja como instituição o batismo tinha uma implicação ainda mais profunda, não tão óbvia, mas de extrema importância do ponto de vista do papel institucional e da sua capacidade e legitimidade de autoridade sobre novos povos. Na medida em que o ritual do batismo introduzia o indivíduo no seio da Igreja, auto referenciada como o novo povo eleito, também colocava esta alma, e o corpo que lhe abriga, sob a jurisdição do catolicismo. Por outros meios, a jurisdição religiosa e moral da Igreja, pela sua própria noção de direito, era restrita a si mesma, ou seja, à comunidade dos batizados. Batizar novos grupos, assim como novos indivíduos, equivalia, ao menos num sentido legalista, submetê-los à autoridade eclesiástica. Por isso era necessário instruí-los nos saberes fundamentais do catolicismo para que pudessem corresponder às expectativas.

\section{DE CRIATURAS A FILHOS DE DEUS}

A partir deste quadro funcional do batismo é possível perceber que os padres e confrades da Societas Iesu nutriam a crença de que por meio da liturgia batismal os pagãos eram constituídos cristãos e filhos de Deus. Nas palavras de Alonso de Sandoval a passagem era de 'escravos do demônio a filhos de Deus'. No entanto, de um modo mais geral, parece que a transformação mais genericamente aceita era de criatura a filhos de Deus. Crença esta, que transparece nos registros de batismos dos recém-nascidos. Fazia-se referência a eles quando nascidos como 'criaturas'. É o que se vê quando o padre Nicolás Gonzales, assim como o já citado Francisco Yolofo, em seu testemunho do zelo apostólico de Pedro Claver na faina de assistir os recém-chegados a Cartagena, relata que o padre buscava saber se havia "nascido alguma criatura" durante a travessia ${ }^{10}$. A mudança ontológica era extensível às crianças, co-herdeiras do pecado de Adáo, e portanto necessitadas do remédio do batismo. Em especial às crianças pagãs, mas também as já nascidas em famílias cristãs.

${ }^{10}$ Splendiani, Anna María e Aristizabal, Tulio (2002): 87 e 114. 
É o que vemos quando nos voltamos para os registros de batismo de da Estância jesuítica de Caroya, no que hoje é o município de Córdoba, Argentina. Lá vemos que o padre Antônio Morales encerra o assento do batismo da pequena Joana, filha de Phelipe Caroya e Magdalena Monserrate. Escreveu ele ao final do registro: "La criatura había nacido dos días antes" (grifo nosso) ${ }^{11}$. Ou seja, quando nasceu era tấo somente uma criatura, com dignidade diminuta. Não obstante a isso, após receber o sacramento tornou-se membro da Igreja, merecendo ser sepultada dentro da capela.

De modo análogo, o padre Bartholome Franco batizou privadamente e por necessidade Maria Clara, em pleno domingo, 16 de abril de 1758. Seus pais, Agustin e Theresa, eram escravos da estância, assim como seus padrinhos de batismo Ignacio Carranza e Victoria sua mulher ${ }^{12}$. Como a pequena Maria Clara resistiu, dois domingos depois, em 30 de abril recebeu os santos óleos e a crisma, tendo por padrinhos de crisma Phelipe e Victoria, até onde sabemos, todos escravos da mesma estância. Decisão acertada a de fazer o quanto antes tudo o que se julgava possível para a salvação da pequena Maria Clara, na quinta-feira seguinte, 4 de maio de 1758, descia à sepultura o corpo inerte da criança.

Para além das crianças, aos adultos provavelmente também se lhes outorgava a mesma necessidade de mudança de estado. Destoando dos demais registros de batismo da estância Caroya, encontramos dois assentamentos assaz interessantes. Trata-se dos únicos casos de batismos coletivos no livro. Nestas duas ocasióes, em 10 de maio de 1761 e no domingo seguinte, foram batizados com toda a solenidade nove escravos de Angola. No dia 10 compareceram a Pia Mathias, Juan Joseph, Maria del Carmem, Juana Josepha e Ana Philipa; no dia 17, foi a vez de Joseph, Juana e Domingas. Não foram apenas os únicos batismos coletivos, mas também os únicos africanos assinalados na fonte.

A partir deste já seco mês de maio da região de Córdoba, este grupo de africanos passaram a ser contados entre os filhos de Deus, sendo vistos pelos padres como portadores de capacidades e obrigados a assumir compromissos. Prova disso é o fato de que Mathias de Angola, dois anos depois ${ }^{13}$ já estava casado com Juliana (aparentemente nascida na América) batizando sua filha Maria em 13 de setembro

${ }^{11}$ Libro de bautismos, casamentos y entierros de esclavos y otros. Cordoba, Argentina: Instituto de Estudios Americanistas. Estancia. Fl. 8V.

${ }^{12}$ Libro de bautismos, casamentos y entierros de esclavos y otros. Cordoba, Argentina. Instituto de Estudios Americanistas. Estancia Caroya. Fl. 2V.

${ }^{13} \mathrm{Na}$ transcrição da fonte a que tivemos acesso, consta a data 1768 , com uma interrogação escrita à caneta, porém o registro foi feito entre os de 1763. Optamos por tomá-lo pelo contexto dos demais registros, considerando um eventual erro no registro, na leitura ou na transcriçẫo. 
de 1763. Tomando os dois registros, vemos que eles espelham três sacramentos para aos quais esteve presente Mathias de Angola: seu batismo, seu casamento e o batismo de sua filha, apadrinhada por Roza, também escrava.

A passagem de criatura a filho de Deus operada em seus escravos representava para os padres um punhado de coisas. Em primeiro lugar, a garantia da salvação daqueles que estavam sob sua responsabilidade, como propriedade coletiva da ordem. Derivando disso, a sua própria salvação, na medida em que cumpriam sua obrigação de pregar a doutrina católica, particularmente cara a eles por serem membros de uma companhia de pregadores. Acrescia a jurisdição eclesiástica sobre os escravos à jurisdição de proprietários, fazendo com que estivessem duplamente subordinados, e por fim, alterava o status de suas propriedades, de criaturas para filhos de Deus. Obviamente, tudo isso está muito mais presente no imaginário dos padres, que no dos cativos, que certamente viam a coisa toda de outra maneira.

\section{REFERENCIAS}

Alencastro, Luis Felipe. O Trato dos Viventes: formação do Brasil no Atlântico sul. São Paulo: Cia das Letras, 2000.

Antonil, André João. Cultura e opulência do Brasil por suas Drogas e Minas. Introdução e notas por André Dinis Silva. São Paulo: Editora Universidade de São Paulo, 2007.

Azopardo, Ildefonso. "Los negros y la Iglesia em la España de los siglos XV y XVI". Em: <http://www.africafundacion.org/IMG/pdf/LOS_NEGROS_Y_ LA_IGLESIA_EN_LA_ESPANA_DE_LOS_SIGLOS_XV_y_XVI.pdf> (Acessado em: 21 de junho de 2012).

Benci, Jorge. Economia cristã dos senhores no governo dos escravos. São Paulo: Grijalbo, 1977.

Bossi, Alfredo. (Org.), Essencial Padre Antônio Vieira, Cia. São Paulo: das Letras, 2011.

Catecismo da Igreja Católica. São Paulo: Ed. Loyola, 2000.

Concilio de Trento. em:<http://www.emym.org/articulos1/conciliodetrento.pdf> (Acessado em: el 22 de maio de 2012). 
Confissão de Augsburgo. Em: http: //www.teologia.org.br/estudos/confissao_de_ augsburgo.pdf (Acessado em: 30 de junho de 2012).

García Villoslada, Ricardo y Llorca, Bernardino. Historia de la Iglesia Católica. Tomo III. Madrid: Edad Nueva, Editora B.A-C, 1960.

Manuscrito Libro de bautismos, casamentos y entierros de esclavos y otros. Instituto de Cordoba: Estudios Americanistas, Estancia Caroya.

Martins, Lepoldo Pires (Ed.), Catecismo Romano. Petrópolis: Ed. Vozes, 1951.

Paulo III, Papa. Laetare Jerusalem. Em:<http://agnusdei.50webs.com/trento3. htm> (Acessado em: 13 de abril de 2012).

Sandoval, Alonso. Um tratado sobre la esclavitud. Madrid: Aliança Editorial, 1987.

Sesboüé et alii. História dos Dogmas. Tomo III. São Paulo: Ed. Loyola, 2005.

Souza, Marina. "Catolicismo e comércio na região do Congo e de Angola, séculos XVI e XVII". Em João Fragoso et al. Nas rotas do Império: eixos mercantis, tráfico e relaçôes sociais no mundo português. Lisboa, IICT, Vitória, EDUFES, 2006.

Splendiani, Ana María y Ariztizabal, Tulio. Processo de beatificación y canonización de san Pedro Claver. Bogotá: CEJA, 2002.

Vainfas, Ronaldo. Ideologia e escravidão. Petrópolis: Ed. Vozes, 1986.

Valtierra, Angel. San Pedro Claver: el santo que libertó una raza. Cartagena, Departamento de Publicaciones - Santuario de San Pedro Claver, 1964.

Vide, Sebastião. Constituiçóes Primeiras do Arcebispado da Bahia, Coimbra, Real Colégio das Artes e da Companhia de Jesus, 1720. Brasilía: Edição do Senado Federal, 2007. 